Indonesian Journal of Physics and Nuclear Applications

Volume 3, Number 1, February 2018, p. 1-6

e-ISSN 2550-0570, (C) FSM UKSW Publication

\title{
Safety Features of Advanced and Economic Simplified Boiling Water Reactors
}

\author{
Ren-Tai Chiang \\ Fellow of American Nuclear Society (ANS)
}

\begin{abstract}
The Advanced Boiling Water Reactor (ABWR) and the Economic Simplified Boiling Water Reactor (ESBWR) are two kinds of contemporary, advanced, commercially available nuclear power reactors. Reactor internal pumps in an ABWR improve performance while eliminating the large recirculation pumps in earlier BWRs. The utilization of natural circulation and passive safety systems in the ESBWR design simplifies nuclear reactor system designs, reduces cost, and provides a reliable stability solution for inherently safe operation. The conceptually reliable stability solution for inherently safe ESBWR operation is developed by establishing a sufficiently high natural circulation flow line, which has a core flow margin at least 5\% higher than the stability boundary flow at $100 \%$ rated power of a conventional BWR, and then by designing a high flow natural circulation system to achieve this high natural circulation flow line. The performance analyses for the ESBWR Emergency Core Cooling System (ECCS) show that: (1) the core remains covered with a large margin and there is no core heat up in the ESBWR for any break size, (2) the long-term containment pressure increases gradually with time, in the order of hours, and the peak pressure is below the design value with a large margin, and (3) the margins depend on the containment volumes and water inventories. These safety design features ensure inherently safe ESBWR operation. Enhanced safety features based on lessons learned from the Fukushima nuclear accident are added in ABWR's and ESBWR's safety designs. The major enhancements are the further prevention of station blackout and loss of ultimate heat sink.
\end{abstract}

Keywords Safety, ABWR, ESBWR, Operation.

\section{INTRODUCTION}

Reactor safety is essential and vital for nuclear power reactor operations. The Boiling Water Reactors (BWRs) have evolved from natural circulation in the Dodewaard BWR to external recirculation pump in BWR-2, to jet pump in BWR-3 to BWR-6, to internal recirculation pump in Advanced BWR (ABWR), and back to natural circulation in Economic Simplified BWR (ESBWR) [1-3]. The ABWR and the ESBWR are two kinds of contemporary, advanced, commercially available nuclear power reactors.

Reactor internal pumps are used in
ABWRs to improve performance while eliminating the large recirculation pumps in earlier BWRs. The utilization of natural circulation and passive safety systems in the ESBWR design simplifies nuclear reactor system designs, reduces cost, and provides a reliable stability solution for inherently safe operation. The ESBWR (1132 assemblies with $4500 \mathrm{MWt}$ rated power) is not just a "step design change" from the small Dodewaard BWR (164 assemblies with $183 \mathrm{MWt}$ rated power), but rather evolves from the design and operating experience of all BWRs in the past five decades.

Four ABWRs used to be operated but temporarily stopped operations after the Fukushima nuclear accident in Japan, one 
ABWR is installed in Taiwan, and two ABWRs are being constructed in the United Kingdom. In the US, DTE Energy received the first ESBWR-based combined construction and operating license from the Nuclear Regulatory Commission in 2015 and Dominion Virginia Power has selected the ESBWR as its technology of choice for a potential third reactor at the North Anna site.

\section{Safety Feature of ABWR}

The safety features of an ABWR include:

1. Reactor internal pumps improve performance while eliminating the large recirculation pumps.

2. A Fully digital Reactor Protection System ensures a high level of reliability and simplification for safety detection and response.

3. Fully digital reactor controls allow the control room to easily and rapidly control plant operations and processes.

4. An Improved Emergency Core Cooling System (ECCS) provides very high level of defense-in-depth against accidents.

After a severe accident, the reactor will be shut down immediately. Decay heat will be removed by the Residual Heat Removal System and the Emergency Core Cooling System will be initiated as needed.

In case of station blackout, the ABWR is fully automated in response to a Loss-ofCoolant Accident (LOCA), and operator action is not required for three days. After three days the operators must replenish ECCS water supplies. These and other improvements make the plant significantly safer than previous reactors.

The GE Probabilistic Risk Assessment (PRA) indicates that a core damage event would occur no more often than once in six million years as the core damage frequency of the ABWR is $1.6 \times 10^{-7}$.

Enhanced safety features based on lessons learned from the Fukushima NPP accident are added. The major enhancements are the further prevention of Station Black Out (SBO) and/or Loss of Ultimate Heat Sink (LUHS). Moreover, water supply into the reactor, primary containment integrity, and spent fuel pool water level are maintained even in the event of SBO and/or LUHS. These enhancements ensure that the integrity of inherent safety features of an ABWR is retained even in the event of a severe accident. These enhanced safety features are also added in an ESBWR.

\section{Safety Feature of ESBWR}

The natural circulation in ESBWR is designed with an unrestricted downcomer, enhanced through optimization on the chimney height, active core length, and separator configurations. The utilization of natural circulation (Figure 1) and passive safety systems in the ESBWR design simplifies reactor system designs, reduces cost, and provides a reliable stability solution for inherently safe operation. The ESBWR core damage frequency at power is $1.7 \times 10^{-8} /$ year, which is the lowest among all advanced reactor designs in nuclear industry. 


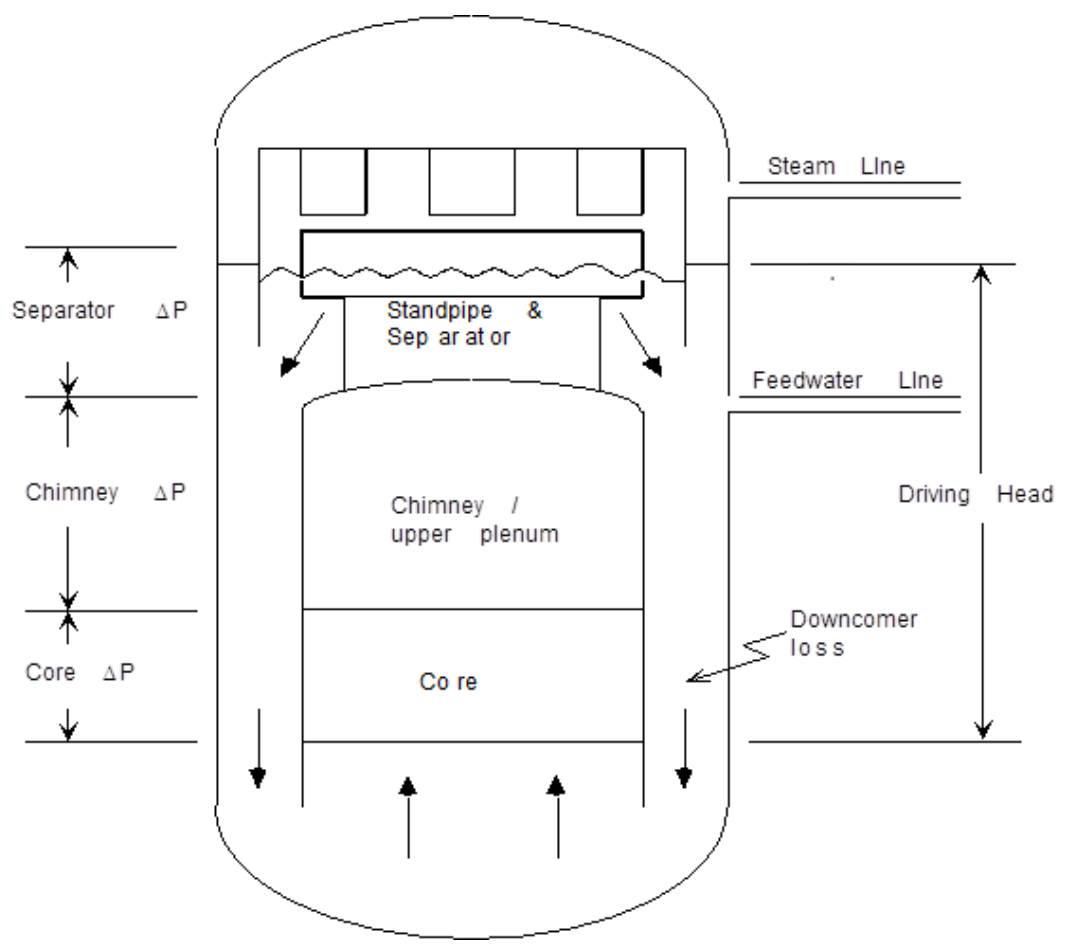

Figure 1. Simplified Diagram of an ESBWR

\subsection{Stability Analysis}

Power oscillations in a BWR primarily can be decomposed into two modes of oscillations: core-wide mode oscillation and regional mode oscillation. The core-wide mode power oscillation is associated with the fundamental mode of neutron flux distribution and core-wide mode bundle (or channel) power oscillations in the entire core are in phase. The regional mode power oscillation is primarily associated with the first harmonics of neutron flux distribution and the regional mode bundle (or channel) power oscillations in a half core are out of phase to the corresponding regional mode bundle power oscillations in the opposite half core. In general, the core-wide mode power oscillation is the dominant mode of power oscillations in a BWR.

BWR instabilities can be analyzed in terms of core and bundle (or channel) power decay ratios. The decay ratio (DR) is defined as the ratio of a peak power to the successive preceding peak power in a power oscillation (with a period on the order of 1 second) after a reactivity perturbation (such as a core flow change) in an operating reactor. Theoretically, if the DR is equal to or larger than one, the oscillation will not decay or will grow and the system is not stable. Therefore, a reactor system (a bundle, a group of bundles, or whole core) must keep its DR less than one to stay stable. Practically, the stability DR acceptance criterion must be much less than one (for example, 0.80) in order to incorporate method uncertainty and adequate safety margin. The BWR instability associated with core-wide mode power oscillations can be analyzed using core DR and the BWR instability associated with regional mode power oscillations and can be analyzed using bundle or channel DR.

The BWR Owners Group issued 
recommended guidelines in 1994 and an update in 2002 for BWR operation [4,5], which emphasize instability prevention. The guidelines define three stability Interim Corrective Actions (ICA) operating regions: Scram, Exit, and Controlled Entry Regions in a power/flow map (as shown in Figure 2) that are excluded from planned entry and prescribe specific actions upon unplanned entry. Since the ICA Regions are based on empirical evaluations and experience, the standard ICA Region boundaries may be validated or expanded based on decay ratio analyses at various region boundary state points that are compared against the decay ratio acceptance criterion for nominal feedwater temperature (FWT) operation and minimum FWT operation on a cycle-specific basis.

An example of expanded ICA Regions of a conventional BWR for minimum FWT operation is shown in Figure 2. Since the expanded ICA Regions for minimum FWT operation bound those for nominal FWT operation, any operation outside the expanded ICA Exit/Controlled Entry Region boundary for minimum FWT operation is adequate for nominal FWT operation. The core DRs at the two bounding state points $\mathrm{A}$ (on the high flow control line) and $\mathrm{B}$ (on the natural circulation line) of the expanded ICA Exit/Controlled Entry Region boundary for minimum FWT operation are 0.787 and 0.300 , respectively, and the corresponding highest channel DRs are 0.251 and 0.233 , respectively. The core and the highest channel DRs at the points A and B satisfy the stability DR acceptance criterion.

A stability boundary is established by connecting the two bounding state points A and $\mathrm{B}$ of the expanded ICA Exit/Controlled Entry Region boundary with a fitting function and by extending the boundary to $100 \%$ rated power as shown in Figure 2. Consequently, the stability boundary plus a conservative (at least 5\%) core flow margin at $100 \%$ rated power can be used to design an inherently safe ESBWR with a sufficiently high natural circulation flow line as shown in Figure 2.

The design of a high flow natural circulation system in an ESBWR can be achieved by: 1) replacing a restricted downcomer with an unrestricted downcomer, i.e., opening up the restricted flow area in a conventional BWR (the jet pump suction in a jet pump BWR or the pump impeller passage in an internal pump BWR), and 2) optimizing the chimney height, active core length, and separator configurations. The natural circulation core flow can be increased significantly, as much as $100 \%$, by replacing a restricted downcomer with an unrestricted downcomer, i.e., from roughly $23 \%$ rated with a restricted downcomer to roughly $46 \%$ rated with an unrestricted downcomer. Moreover, the natural circulation core flow can be further increased from $46 \%$ rated to over $70 \%$ rated with a flow margin at least $5 \%$ higher than the stability boundary flow at $100 \%$ rated power by optimizing the chimney height, active core length, and separator configurations. 


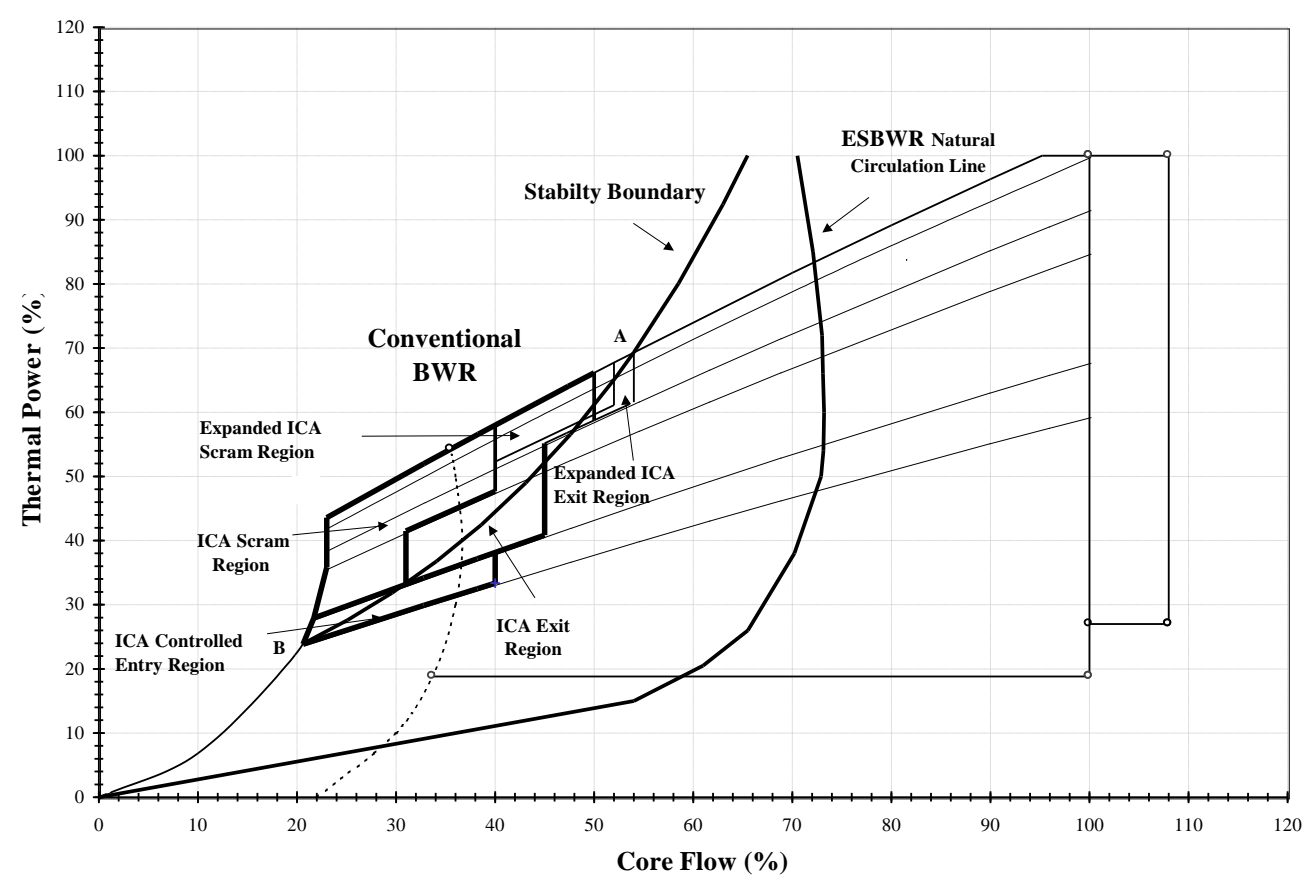

Figure 2 Comparison between ESBWR and Conventional BWR Power/Flow Maps

\subsection{Performance Analyses of ECCS and Containment System}

Performance analyses for the 4500 MWth ESBWR ECCS were made for a spectrum of LOCA events [6]. These calculations accounted for uncertainties and biases in the computer models and used conservative initial conditions and plant parameters. Results of these performance analyses show that: (1) core remains covered with large margin and there is no core heatup in the ESBWR for any break size, (2) the long-term containment pressure increases gradually with time, in the order of hours, and the peak pressure is below the design value with a large margin, and (3) the margins depend on the containment volumes and water inventories.

\section{Conclusions}

The safety features of ABWR and ESBWR have been discussed. Reactor internal pumps have been used in ABWRs to improve performance while eliminating the large recirculation pumps in earlier BWRs.

The conceptually reliable stability solution for inherently safe ESBWR operation has been developed by establishing a sufficiently high natural circulation flow line, which has a core flow margin at least 5\% higher than the stability boundary flow at $100 \%$ rated power of a conventional BWR, and then by designing a high flow natural circulation system to achieve this high natural circulation flow line. The design of a high flow natural circulation system in an ESBWR can be achieved by replacing a restricted downcomer with an unrestricted downcomer and by optimizing the chimney height, active core length, and separator configurations.

The performance analyses for the ESBWR ECCS show that: (1) the core remains covered with a large margin and there is no core heatup in the ESBWR for any break size, (2) the longterm containment pressure increases gradually 
with time, in the order of hours, and the peak pressure is below the design value with a large margin, and (3) the margins depend on the containment volumes and water inventories. These safety design features ensure inherently safe ESBWR operation.

Enhanced safety features based on lessons learned from the Fukushima NPP accident have been added in ABWR's and ESBWR's safety designs. The major enhancements are the further prevention of station blackout and loss of ultimate heat sink.

\section{REFERENCES}

BWROG-94079, "BWR Owner's Group Guidelines for Stability Interim Corrective Action," June 1994.

BWROG-02072, "Review of BWR Owners' Group Guidelines for Stability Interim Corrective Action," November 2002.

Cheung et al., Y.K., "Design Evolution of Natural Circulation in ESBWR," 6th Int. Conf. on Nuclear Engineering, San Diego, CA, USA, May 10-15, 1998.

Cheung et al., Y.K., "Performance Analyses of ECCS and Containment Systems for the 4500 MW ESBWR," Proc. International congress on advances in nuclear power plants - ICAPP'06, Reno, Nevada, USA, June 4-8, 2006.

Chiang, R.T. , Y. Sardjono and R.M. Fawcett, "Spectral Shift Benefit on ABWR Core Designs," Proc. Int. Conf. on Physics. of Nuclear Science and Technology, 1685, Long Island, N.Y., USA, October 5-8, 1998.

Chiang et al., R.T., "Impacts of Fuel Design, Core Design and Reactor Operation on BWR Stability Behaviour," Proc. Advances in Nuclear Fuel Management - III, Hilton Head Island, SC, USA, October 5-8, 2003. 